\title{
HEPATOTOXICITY OF TEMSIROLIMUS AND INTERFERON ALPHA IN PATIENTS WITH METASTASISED RENAL CANCER: A CASE STUDY
}

\author{
Bojana Petrovic ${ }^{1}$, Sinisa Radulovic ${ }^{2}$ \\ ${ }^{1}$ Medical Faculty, University of Kragujevac, Serbia \\ 2 Institute for Oncology and Radiology of Serbia, Belgrade, Serbia
}

\section{HEPATOKSIČNOST TEMSIROLIMUSA I INTERFERONA ALFA KOD PACIJENATA SA METASTATSKIM KARCINOMOM BUBREGA: SERIJA SLUČAJEVA}

\author{
Bojana Petrović ${ }^{1}$, Siniša Radulović ${ }^{2}$ \\ Medicinski fakultet Univerziteta u Kragujevcu, Srbija \\ Institut za onkologiju i radiologiju Srbije, Beograd, Srbija
}

Received / Primljen: 21. 4. 2011.

Accepted / Prihvaćen: 25. 05. 2011.

\section{ABSTRACT}

Temsirolimus is a drug used for the treatment of renal cell carcinoma. The target of action of temsirolimus is mTOR (mammalian target of rapamycin) kinase, a cellular protein that regulates the growth of tumour cells and blood vessels. The aim of the present study was to determine whetherif temsirolimus has greater hepatotoxic potential than standard therapies for renal cancer, including interpheron alpha and vinblastine.

The current study was conducted on patients treated at the Institute for Radiology and Oncology of Serbia, Belgrade for metastasised renal cell carcinoma. In total, nine patients were administered $25 \mathrm{mg}$ of temsirolimus per week for four weeks. Another fourteen patients were treated with standard therapy, including interferon alpha (6 MJ, three times a week) and vinblastine (10 mg, two days per cycle, for four cycles). Biochemical parameters of liver function (aspartate amino-transferase, alanine amino-transferase, alkaline phosphatase, lactate dehydrogenase, $\gamma$ glutamine trans-peptidase, bilirubine [direct and totall and serum proteins) were analysed prior to administration and four weeks after treatment.

In total, six patients developed hepatotoxicity, which was defined as a 3-fold increase in aspartate amino-transferase and alanine amino-transferase levels after the administration of therapy. Three patients showing signs of hepatotoxicity received temsirolimus, and three were treated with interferon alpha and vinblastine. Except for the level of aspartate amino-transferase, the studied factors including age, sex, drug, diabetes, heart failure, hypertension, nephrectomy, stage of cancer and serum urea and creatinine levels were not associated with hepatotoxicity. Namely, in patients who experienced hepatotoxicity, the aspartate amino-transferase content was significantly lower prior to the administration of drugs (13.3 \pm 6.1 vs. 20.1 $\pm 7.4 ; T=-2.400, d f=12, p=0.033$ ).

The results of the present case study suggest that temsirolimus is not more hepatotoxic in patients with metastasised renal cancer than standard therapies such as interferon alpha and vinblastine.

Key words. Temsirolimus; liver; toxicity; metastasised renal cancer.

\section{SAŽETAK}

Temsirolimus se koristi u lečenju karcinoma bubrega, jer onemogućava stvaranje novih krvnih sudova neophodnih za sirenje tumora. Ove efekte temsirolimus postiže inhibicijom posebne tirozin - kinaze (kinaze za koju se vezuje rapamicin kod sisara). Cilj naše studije je bio da ispita da li temsirolimus ima veći hepatotoksični potencijal od standardne terapije metastatskog carcinoma bubrega, kombinacije interferona alfa $i$ vinblastina.

Studija je sprovedena kod pacijenata sa metastatskim karcinomom bubrega lečenih na Institutu za onkologiju i radiologiju Srbije u Beogradu. Bilo je 9 pacijenata koji su uzimali temsirolimus $25 \mathrm{mg}$ nedeljno, tokom 4 nedelje. Drugih 14 pacijenata je bilo na standardnoj terapiji (interferon alfa 6 M. tri puta nedeljno) $i$ vinblastin $10 \mathrm{mg}$ dva dana u ciklusu, tokom 4 ciklusa. Kod pacijenata su analizirani biohemijski parametri funkcije jetre na dolasku i četiri nedelje nakon uvodenja terapije: transaminaze (aspartat aminotransferaza $i$ alanin aminotransferaza), alkalna fosfataza, laktat dehidrogenaza, gama glutamin transpeptidaza, bilirubin (direktni i ukupni), i proteini u serumu.

Bilo je šest pacijenata kod kojih je došlo do oštećenja jetre, definisanog kao najmanje trostruki porast serumskog nivoa aspartat aminotransferaze $i$ alanin aminotransferaze posle primene terapije: troje od njih je primilo temsirolimus, a troje interferon alfa $i$ vinblastin. Nijedan od ispitivanih faktora (starost, pol, lek, dijabetes, insuficijencija srca, hipertenzija, nefrektomija, stadijum carcinoma, nivo uree $i$ kreatinina $u$ serumu) nije bio udružen da hepatotoksičnošću, izuzev nivoa aspartat aminotransferaze, koji je pre primene lekova bio značajno niži kod pacije-

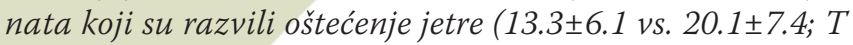
$=-2.400, d f=12, p=0.033$ ).

Rezultati naše serije slučajeva sugerišu da temsirolimus nije više hepatotoksičan kod pacijenata sa metastatskim karcinomom bubrega od standardne terapije kombinacijom interferona alfa $i$ vinblastina.

Ključne reči. Temsirolimus; jetra; toksičnost; metastatski karcinom bubrega. 


\section{INTRODUCTION}

Temsirolimus binds mTOR (mammalian target of rapamycin) kinase, a cellular protein that regulates the growth of tumour cells and blood vessels. An intravenous preparation of temsirolimus was developed by Wyeth and received marketing authorisation from the Food and Drug Administration in May 2007 and from the European Medicine Agency in November 2007 for the treatment of metastasised renal cell cancer (RCC). ${ }^{1,2}$

Kinase mTOR (mammalian target of rapamicin) is a component of intracellular signalling pathways involved in the growth and division of cells and in the cellular response to hypoxia. Temsirolimus binds FKBP-12, an intracellular protein, forming a complex that inhibits signals initiated by mTOR. The blockage of mTOR signals prevents the production of proteins that regulate cell cycle progression and angiogenesis. ${ }^{3,4,5,6}$

In general, temsirolimus is efficacious in patients with metastasised renal cell cancer, and it causes adverse effects of moderate severity. The most frequent side effects of temsirolimus include rash, nausea, weakness, inflammation of mucous membranes, anorexia and anemia., 7,9

The aim of the present study was to determine whetherif temsirolimus is more hepatotoxic than standard therapies for metastasised renal cancer, including interpheron alpha and vinblastine.

\section{MATERIALS AND METHODS}

\section{The patients}

The present observational study was conducted on patients treated at the Institute for Oncology and Radiology of Serbia, Belgrade for metastasised renal cell cancer from January $1^{\text {st }}, 2000$ to April $1^{\text {st }}, 2007$. In total, 23 patients were included in the study. Nine patients (average age $59.2 \pm 7.2$ years) received $25 \mathrm{mg}$ of temsirolimus per week (for four weeks) and 14 patients (average age $54.6 \pm 9.8$ years) were treated with interferon alpha (6 MJ, three times a week) and vinblastine (10 $\mathrm{mg}$, two days per cycle, for four cycles). The study was approved by the research committee of the Institute for Oncology and Radiology of Serbia.

\section{The variables}

Biochemical parameters of liver function (aspartate amino-transferase, alanine amino-transferase, alkaline phosphatase, lactate dehydrogenase, $\gamma$ glutamine trans-peptidase, bilirubine [direct and total] and serum proteins) and the concentration of serum urea, creatinine, sodium, potassium and calcium were analysed prior to drug administration and four weeks after treatment. The patient's age, sex, chronic diseases, therapy and stage of cancer were obtained from their files.

\section{Statistics}

The prevalence of each risk factor was determined for patients with liver injury (cases) and patients with normal serum levels of liver enzymes (controls). Differences between patients with liver injury and those in the control group were assessed with a Student T-test for continuous variables and with a Fisher's exact test for frequencies. Differences were considered significant when the probability of the null hypothesis was less than 0.05 . To estimate the association between potential risk factors and hepatotoxicity, crude and adjusted odds ratios (OR) with $95 \%$ confidence intervals $(95 \% \mathrm{CI}$ ) were calculated using logistic regression ${ }^{10,11}$.

\section{RE SULTS}

The study population included 23 patients with metastasised renal cell cancer. The characteristics of patients with and without liver injury are shown in Table 1. Significant differences in the age, sex, nephrectomy, hypertension, chronic heart failure, diabetes, drugs, grade of tumour, skin rash, serum urea level and creatinine and alanine amino-transferase levels content of patients were not observed among groups. However, prior to treatment, significant differences in the serum level of aspartate aminotransferase were detected (see Table 1).

The results of logistic regression analysis (Cox \& Snell $R^{2}=0.486$, Nagelkerke $R^{2}=0.713$, Hosmer and Lemeshow $\left.\mathrm{Chi}^{2}=3.187, \mathrm{df}=8, \mathrm{p}=0.922\right)$ with adjustments for potential confounders are shown in Table 2. As shown in the table, significant associations between liver injury and the studied factors were not observed. Although the adjusted odds ratio for drugs and tumour grade were 16.64 and 4.88, respectively, the confidence limit included the value of one, indicating that the association was not significant.

\section{DISCUSSION}

In several phase II and III clinical trials on temsirolimus, the following adverse effects were observed: skin rash (47\%), weakness $(51 \%)$, inflammation of mucous membranes (41\%), nausea (37\%), edema (35\%) and loss of appetite (32\%). ${ }^{12,13}$

Serious adverse reactions to temsirolimus have been reported, including hypersensitivity reactions (skin redness, chest pain and/or breathing difficulties), extreme hyperglycaemia, interstitial lung disease, intestinal perforation and acute renal insufficiency. The most frequent laboratory abnormalities in patients receiving temsirolimus were anaemia (94\%), hyperglycaemia (89\%), hyperlipidaemia (87\%), hypertriglyceridemia (83\%), increased serum levels of alkaline phosphatase (68\%), aspartate amino-transferase (38\%) and creatinine (57\%), lymphopenia (53\%), hypophosphatemia (49\%), decreased platelet count (40\%), and leukopenia (32\%). ${ }^{14,15,16}$

In the present study, surrogate markers for liver injury (a 3-fold increase in the serum level of aspartate aminotransferase and alanine amino-transferase compared to 


\begin{tabular}{|c|c|c|c|c|}
\hline Variable & $\begin{array}{l}\text { Patients with elevated } \\
\text { serum levels of liver } \\
\text { enzymes ( } 3 \text {-fold } \\
\text { higher than the } \\
\text { baseline }(n=6) \text { ) }\end{array}$ & $\begin{array}{l}\text { Patients without el- } \\
\text { evated serum levels of } \\
\text { liver enzymes }(n=17)\end{array}$ & $\begin{array}{l}\text { Test value and } \\
\text { significance of null } \\
\text { hypothesis }\end{array}$ & $\begin{array}{l}\text { Crude odds ratios and } \\
\text { confidence intervals } \\
(1.96 \% \mathrm{SE})\end{array}$ \\
\hline $\operatorname{Sex}(M / F)$ & $5 / 1(83 \% / 17 \%)$ & $12 / 5(71 \% / 29 \%)$ & Fisher's $\mathrm{p}=1.000$ & $2.08(0.19,22.66)$ \\
\hline Age (years, mean $\pm \mathrm{SD}$ ) & $60.1 \pm 7.3$ & $54.5 \pm 9.1$ & $\mathrm{~T}=1.380, \mathrm{p}=0.182$ & $1.09(0.96,1.25)$ \\
\hline Nephrectomy (yes/no) & $6 / 0(100 \% / 0 \%)$ & $16 / 1(94 \% / 6 \%)$ & Fisher's $\mathrm{p}=1.000$ & $504.14(0.00,>1000)$ \\
\hline Diabetes mellitus (yes/no) & $0 / 6(0 \% / 100 \%)$ & $4 / 13(24 \% / 76 \%)$ & Fisher's $\mathrm{p}=0.539$ & $0.00(0.00,>1000)$ \\
\hline Hypertension (yes/no) & $2 / 4(34 \% / 66 \%)$ & $6 / 11(36 \% / 64 \%)$ & Fisher's $\mathrm{p}=1.000$ & $0.92(0.12,6.56)$ \\
\hline $\begin{array}{l}\text { Tumour grade } \\
(\mathrm{C} 64 / \mathrm{C} 65 / \mathrm{C} 61 / \mathrm{C} 67 / \mathrm{C} 25)\end{array}$ & $\begin{array}{l}4 / 1 / 1 / 0 / 0 \\
(66 \% / 17 \% / 17 \% / 0 \% / 0 \%)\end{array}$ & $\begin{array}{l}13 / 2 / 0 / 1 / 1 \\
(76 \% / 12 \% / 0 \% / 6 \% / 6 \%)\end{array}$ & $x^{2}=3.679, p=0.451$ & $0.97(0.40,2.38)$ \\
\hline $\begin{array}{l}\text { Chronic heart failure } \\
\text { (yes/no) }\end{array}$ & $2 / 4(34 \% / 66 \%)$ & 6/11 (36\%/64\%) & Fisher's $\mathrm{p}=1.000$ & $0.92(0.13,6.56)$ \\
\hline Skin rash (yes/no) & $3 / 3(50 \% / 50 \%)$ & $6 / 11(36 \% / 64 \%)$ & Fisher's $\mathrm{p}=1.000$ & $1.83(0.28,12.07)$ \\
\hline $\begin{array}{l}\text { Drug (temsirolimus/ } \\
\text { interferon+vinblastine) }\end{array}$ & $3 / 3(50 \% / 50 \%)$ & $6 / 11(36 \% / 64 \%)$ & Fisher's $\mathrm{p}=0.643$ & $1.83(0.28,12.07)$ \\
\hline $\begin{array}{l}\text { Serum urea content } \\
\text { before treatment }(\mathrm{mM} / \mathrm{l})\end{array}$ & $6.4 \pm 1.1$ & $6.7 \pm 3.1$ & $\mathrm{~T}=-0.200, \mathrm{p}=0.843$ & $0.96(0.67,1.39)$ \\
\hline $\begin{array}{l}\text { Serum creatinine content } \\
\text { before treatment }(\mu \mathrm{M} / \mathrm{l})\end{array}$ & $117.5 \pm 28.4$ & $120.7 \pm 47.0$ & $\mathrm{~T}=-0.156, \mathrm{p}=0.877$ & $0.99(0.98,1.02)$ \\
\hline $\begin{array}{l}\text { Serum aspartate amino- } \\
\text { transferase content before } \\
\text { treatment (IU/l) }\end{array}$ & $13.4 \pm 6.1$ & $21.1 \pm 8.4$ & $\mathrm{~T}=-2.400, \mathrm{p}=0.033^{*}$ & $0.83(0.67,1.01)$ \\
\hline $\begin{array}{l}\text { Serum alanine amino- } \\
\text { transferase content before } \\
\text { treatment (IU/l) }\end{array}$ & $15.5 \pm 12.4$ & $20.1 \pm 7.4$ & $\mathrm{~T}=-1.090, \mathrm{p}=0.288$ & $0.94(0.83,1.06)$ \\
\hline
\end{tabular}

"significant difference

Table 1. Characteristics of the Patients.

baseline values) did not display a stronger association with temsirolimus than standard medications for metastasised renal cancer. However, in three out of nine patients (33\%) temsirolimus was associated with liver injury. The causal relationship between temsirolimus and liver injury was rated as probable because liver injury was temporally related to the administration of temsirolimus, and liver enzyme serum levels normalised after temsirolimus treatments were ceaseddechallenging. The standard therapy (interferon alpha plus vinblastine) caused liver injury in 3 out of 11 patients (27\%); however, the observed difference in the rate of liver injury among groups cannot be considered significant due to the small number of patients. Hepatotoxicity was observed in both therapeutic regimens and should be taken into account during the treatment of patients.

Temsirolimus is administered to patients with metastasised renal cell cancer due to its effectiveness. ${ }^{11}$ The results of the present study suggest that mild liver injury can be

Table 2. Crude and adjusted odds ratios of the risk factors for liver injury in patients with metastasised renal cell cancer receiving temsirolimus or interferon alpha and vinblastine.

\begin{tabular}{|l|l|l|}
\hline Risk factors & Crude OR (95\% CI) & Adjusted* OR (95\% CI) \\
\hline $\begin{array}{l}\text { Drug (temsirolimus/ } \\
\text { interferon+vinblastine) }\end{array}$ & $1.83(0.28,12.07)$ & $16.64(0.07,4142.91)$ \\
\hline Tumour grade & $0.97(0.40,2.38)$ & $4.88(0.13,180.87)$ \\
\hline Hypertension & $0.92(0.12,6.56)$ & $0.75(0.01,99.18)$ \\
\hline Serum urea content before treatment & $0.96(0.67,1.39)$ & $0.80(0.18,3.45)$ \\
\hline $\begin{array}{l}\text { Serum aspartate amino-transferase con- } \\
\text { tent before treatment }\end{array}$ & $0.83(0.67,1.01)$ & $0.77(0.58,1.02)$ \\
\hline
\end{tabular}

* Adjusted for age†, sex†, nephrectomy†, hypertension, chronic heart failure $\dagger$, diabetes $\dagger$, drug, tumour grade, skin rash†, serum level of urea, creatininet, aspartate amino-transferase and alanine amino-transferase + .

+Crude and adjusted odds ratios are not shown in the table for the sake of clarity.

$\mathrm{OR}=$ odds ratio 
expected with the use of temsirolimus. To prevent severe forms of liver injury, serum levels of liver enzymes should be measured weekly during the first month of therapy and monthly thereafter.

\section{REFERENCES}

1. Negrier S. Temsirolimus in metastatic renal cell carcinoma. Ann Oncol 2008; 19: 1369-1370.

2. Waxman J, Kenny L, Ngan S. New treatments for kidney cancer. BMJ 2008; 336: 681-682.

3. Fazio N, Dettori M, Lorizzo K, Ferretti G, Hudes G. Temsirolimus for Advanced Renal-Cell Carcinoma. NEJM 2007; 357: 1050-1051.

4. Rini BI. Temsirolimus, an Inhibitor of Mammalian Target of Rapamycin. Clin. Cancer Res 2008; 14: 1286-1290.

5. Hutson TE, Figlin RA, Kuhn JG, Motzer RJ. Targeted Therapies for Metastatic Renal Cell Carcinoma: An Overview of Toxicity and Dosing Strategies. The Oncologist 2008; 13: 1084-1096.

6. Raymond E, Alexandre J, Faivre S, et al. Raymond E, Alexandre J, Faivre S, Vera K, Materman E, Boni J, Leister C,Korth-Bradley J, Hanauske A, Armand JP. Safety and pharmacokinetics of weekly intravenous infusion of CCI-779, a novel mTOR inhibitor, in patients with cancer. J Clin Oncol 2004; 22: 2336-2347.

7. Mekhail TM, Abou-Jawde RM, Boumerhi G, Malhi S, Wood L, Elson P, Bukowski R. Validation and extension of the Memorial Sloan-Kettering prognostic factors model for survival in patients with previously untreated metastatic renal cell carcinoma. J Clin Oncol 2005; 23: 832-841.

8. Skotnicki JS, Leone CL, Smith AL. Design, synthesis and biological evaluation of $\mathrm{C}-42$ hydroxyesters of rapamycin: the identification of CCI-779. Clin Cancer Res 2001; 7Suppl: 3749S-3750S.
9. Harding MW. Immunophilins, mTOR, and pharmacodynamic strategies for a targeted cancer therapy. Clin Cancer Res 2003; 9: 2882-2886.

10. Machin D, Campbell MJ, Walters SJ. Medical Statistics, a textbook for the health sciences. $4^{\text {th }}$ edition, John Wiley \& Sons Ltd., Chichester, U.K., 2007.

11. Perera R, Heneghan C, Badenoch D. Statistics Toolkit. $1^{\text {st }}$ edition, Blackwell Publishing, Oxford, U.K., 2008.

12. Atkins MB, Hidalgo M, Stadler WM, Logan TF, Dutcher JP, Hudes GR, Park Y, Liou SH, Marshall B, Boni JP, Dukart G, Sherman ML. Randomized phase II study of multiple dose levels of CCI-779, a novel mammalian target of rapamycin kinase inhibitor, in patients with advanced refractory renal cell carcinoma. J Clin Oncol 2004; 22: 909-918.

13. Smith II JW, Ko Y, Dutcher J, et al. Phase $1 / 2$ study of intravenous CCI-779 given in combination with interferon- $\alpha$ to patients with advanced renal cell carcinoma. Proc Am Soc Clin Oncol 2004; 22Suppl: 14S.

14. Bukowski RM, Negrier S, Elson P. Prognostic factors in patients with advanced renal cell carcinoma: development of an international kidney cancer working group. Clin Cancer Res 2004; 10: 6310S-6314S.

15. Bellmunt J, Szczylik C, Feingold J, Strahs A, Berkenblit A. Temsirolimus safety profile and management of toxic effects in patients with advanced renal cell carcinoma and poor prognostic features. Ann Oncol 2008; 19: 1387-1392.

16. Hidalgo M, Buckner JC, Erlichman C, Pollack MS, Boni JP, Dukart G, Marshall B, Speicher L, Moore L, Rowinsky EK. A phase I and pharmacokinetic study of temsirolimus (CCI-779) administered intravenously daily for 5 days every 2 weeks to patients with advanced cancer. Clin Cancer Res 2006; 12: 5755-63.

17. Biswas S, Kelly J, Eisen T. Cytoreductive Nephrectomy in Metastatic Clear-Cell Renal Cell Carcinoma: Perspectives in the Tyrosine Kinase Inhibitor Era. The Oncologist 2009; 14: 52-59. 